\title{
Keywords for Children's Literature: mapping the critical moment
}

\author{
Philip $\mathrm{Nel}^{1 \star}$ and Lissa Paul ${ }^{2 \star}$ \\ ${ }^{1}$ Department of English, Kansas State University, Manhattan, KS, USA; ${ }^{2}$ Faculty of Education, \\ Brock University, St. Catharines, Ontario, Canada
}

\begin{abstract}
As Anglophone co-editors of Keywords for Children's Literature, we (Philip Nel and Lissa Paul) were delighted to be invited as keynote speakers for the Nordic Children's Literature Conference in Oslo. When we gave our live talk in August 2012, we staged it is as a performance, a dialogue accompanied by PowerPoint images. Because our performance would not work on the page, we composed a print version of our talk to read both as a coherent prose narrative, and as a reflection on ways in which we were shaped by the occasion. In keeping with one of the central mandates of the conference- "to serve as a meeting point for new research environments"-we decided to open our talk on Keywords for Children's Literature by positioning it in the research environments in which it began. We later explained how the book "works," and concluded by projecting ways in which we might situate it in emerging research environments.
\end{abstract}

Keywords: keywords; children's literature; editing

\section{IMAGINING KEYWORDS FOR CHILDREN'S LITERATURE}

Our book is just one of a cluster of academic works in English published in the last few years mapping a contemporary critical moment in the study of (predominantly Anglophone) children's literature. It sits in the company of other major works of scholarship in the field, including: Julia Mickenberg and Lynne Vallone's Oxford Handbook of Children's Literature (2011), Matthew Grenby and Andrea Immel's Cambridge Companion to Children's Literature (2009), Jack Zipes' Oxford Encyclopedia of Children's Literature (2006) and The Norton Anthology of Children's Literature (2005), edited by Jack Zipes, Lissa Paul, Lynne Vallone, Peter Hunt and Gillian Avery. Each book contributes in its way to the gradual construction of a working scholarly apparatus. What distinguishes our book from the others is that Keywords for Children's Literature aims to provide historical context and clarification to the critical terms that have been all too often used cavalierly or without sufficient focus on their origins and/or disciplinary contexts. Keywords to Children's Literature is an attempt to map the critical terrain of studies in children's literature.

We appreciate that scholarship in children's literature does have a long and honourable historydating from Mrs. Trimmer's early-nineteenthcentury Guardian of Education and F. J. Harvey Darton's early-twentieth-century Children's Books in England - but we made a conscious decision in our presentation to focus only on critical mapping activities dating from the late 1960 s as they coincided with the explosion of children's books published for the post-war baby-boom market. The pace of the critical mapping picked up during the same period, beginning with the establishment in the early 1970s of scholarly journals, such as Signal, Children's Literature in Education and Children's Literature. As the body of scholarship developed, books surveying the critical terrain began to appear, including the three volumes of Touchstones: Reflections on the Best in Children's Literature (1985, 1987 and 1989), and the first scholarly post-structuralist overviews dedicated to mapping the field: Peter Hunt's Children's Literature: The Development of Criticism (1990) and then his Routledge Encylopedia of Children's Literature

*Correspondence to: Lissa Paul, Faculty of Education, Brock University, St. Catharines, Ontario, Canada. Email: lpaul@brocku.ca; Philip Nel, Department of English, Kansas State University, Manhattan, KS 66506-6501, USA. Email: philnel@ksu.edu 
(1993). That sudden burst of scholarly work on children's literature emerged not just because of the boom in the book market, but because the critical climate had changed. The toppling of New Criticism (which had been hostile to scholarship on children's literature) as the dominant critical mode in the late 1960s and early 1970s coincided with a corresponding rise of Feminist Studies, African-American Studies, Cultural and Post-colonial Studies, all of which offered not only more productive critical strategies but also an openness to works previously considered unsuitable for academic inquiry. Only then did Children's Literature begin to receive serious scholarly attention in the literature departments. In the context of the range of post-structuralist critical approaches that developed at the end of the twentieth century, children's literature criticism generally, and our book in particular, was inspired in part, via a discipline, American Studies, noted for bringing many disparate subjects into its sphere.

Keywords for Children's Literature really began in 2007 when Phil attended a week-long Futures of American Studies Institute at Dartmouth College, and Glen Hendler stepped up to the podium to talk about his new Keywords for American Cultural Studies, a book he had co-edited with Bruce Burgett and that would be published later that year. Hendler circulated a photocopied list of the 64 words that would appear in the book: African, Class, Democracy, Exceptionalism, Gender, Indian, Public, Religion, Secularism, Sex, Slavery and White. Noting that Children and Childhood were not present in the list, Phil then had an epiphany: Why not a Keywords for Children's Literature? He began jotting down ideas: Picture books, Family, Cross-Writing, Gender, Audience. Phil immediately recognised that Keywords for Children's Literature was a book he would like to read, but, fearing he did not know enough people in the field to author essays on the keywords he had generated, he enlisted Lissa, as co-editor, to help. And so, we began.

Generally, we knew that we wanted our Keywords for Children's Literature to follow in the spirit of Raymond Williams's influential 1976 Keywords by offering "an exploration of the vocabulary of a crucial area of social and cultural discussion." For Williams, the contentiousness of a particular theoretical term was the defining feature. So during our initial word-selection process, we used "contested" and "conflicted" as a litmus test for determining the viability of potential keywords. We considered whether or not we had seen or heard individual words used, as Williams says, in "inter- esting or difficult ways" (14). Similar to Williams, we also wanted our book to unlock discussions of society and culture that have endured into the twenty-first century, even as the terms and their definitions have shifted. "Keywords" itself is a case in point. Its definition depends on its discipline. For librarians, keywords are search terms identifying the main content of a document. For educators, keywords are high-frequency words (so used in the "look-say" method of reading instruction). And for literary and cultural studies scholars, the word "keywords" conjures up Raymond Williams's coinage and his definitions of words used to explain the sociology of language.

In children's literature studies, critical keywords, in Raymond Williams's sense, present particularly complicated problems, primarily because people working in the field come from so many disciplines. Since the 1970s people from literature, education, library and information science, as well as from culture and media studies, all claimed to be working as scholars in the field of children's literature. The problem is that because they are from disparate disciplines they were often using the same terms to convey very different clusters of ideas. As a result, meanings were often blurred, and cross-disciplinary conversations confused. Yet, the linguistic confusion that arose because of the cross-disciplinarity is the very thing that provided the impetus for Keywords for Children's Literature, and, we hope, will nourish its potential market. As the world shrinks, with new technologies bridging cultures and countries, there is perhaps a greater need to change the disciplinary maps than ever before.

\section{CHOOSING KEYWORDS}

When terrain is uncharted, disciplinary maps, like all maps, are difficult to make. So, it was only as we began to articulate our reasons for excluding particular keywords that we developed a clearer sense of what words we wanted to include. We rejected words that were methodologies because we did not want to fix meanings in place-as a reference work such as a dictionary or encyclopedia might - but rather we wanted to map out a nexus of interconnected ideas. So, for instance, despite the popularity of psychological approaches, Freudian does not appear as a keyword-though both Freudian and Freud appear in the book. The keywords Childhood, Culture, Gender, Home, Identity, Innocence and Theory all invoke Freud by name. Freud's ideas have been contested, but the term 
Freudian - though important-has not been contested sufficiently to qualify as a keyword.

Given our inclusion of African American and Latino/a we also considered including Asian American and Native American, as both are interesting, difficult and contested (so in keeping with the keywords mandate). However, both lacked the necessary sustained body of literature and surrounding critical discourse to justify inclusion. What our discussion did reveal, however, was a distinct bias towards the American side of AngloAmerican. We understand the bias: our Keywords for Children's Literature was itself partly inspired by Keywords for American Studies. We are both acutely aware-especially in the light of our limited linguistic abilities - that one of the last divides in children's literature studies is that Anglophones have limited access to primary texts not published in English. Only Lissa had ever taught a Norwegian children's book in translation: Zeppelin by Tormod Haugen, published 20 years ago in a short-lived publishing venture by Aidan Chambers.

Even in the early stages of the development of Keywords for Children's Literature, we knew that our volume would be provisional. In the end, we did make a conscious editorial decision to focus on critical words used in Anglophone discussions and concentrate on providing access to words migrating between disciplines. We did, for example, decide to include Liminality, a word that has migrated from Anthropology, as the author of the essay, Michael Joseph, explains. He elegantly defines "liminality" as "the quality of being socially segregated, set apart and divested of status" and includes related characteristics such as "indeterminacy, ambiguity, selflessness and becomingness," all strangely appropriate for the discussions of children's literature criticism itself. Although we appreciated that liminality was not exactly a commonly used word, its currency in children's literature studies was on the rise, so we decided to include it. If we decide to undertake a revised Keywords for Children's Literature in a decade or so, we hope to be able to see how critical conversations have evolved and consider terms arising out of a more global and more digital landscape.

\section{WRITING KEYWORDS}

For our initial attempt, however, our major problem was to match selected words with scholars in disciplines related to children's literature: authors, literary scholars, librarians and educators. We wanted people from Anglophone countries, so British, Americans, Canadians and Australians. We needed people who possessed depth of knowledge and who could be trusted to communicate with grace and economy to people across disciplinary - if not linguistic - bounds. Keywords essays, were, and are, tricky to write. They are expository theory. They are etymologies. They have to have clear chronological and critical lines. They need examples not just from children's literature, but also from different kinds of literature, and, as much as possible, we wanted works from different eras and countries, works by people of different genders, ethnicities and nationalities. Ideally, the examples from children's books also had to be situated in the context of literary histories and traditions unmarked as being for children. And each essay had to be readable, elegant and to the point. We wanted educated general readers to be able to pick up the book, flip to an entry and find the information presented in an accessible manner. They are very hard essays to write.

As Children's Literature itself was a difficult-todefine term, one of the first potential contributors we approached was someone who had already constructed a significant body of work on the term: Peter Hunt. His well-researched and comprehensive essay begins by locating the central problem. "Children's Literature," he says, "is a term used to describe both a set of texts and an academic discipline - and it is often regarded as an oxymoron. If 'children' commonly connotes immaturity and 'literature' commonly connotes sophistication in texts and reading, then the two terms may seem to be incompatible" (42). ${ }^{1}$ Hunt resolves the simple/complex dichotomies by invoking Raymond Williams:

\begin{abstract}
Both parts of the term [children and literature] are what Raymond Williams (1976/ 1983a) would have called difficult in that both cover a huge range of meanings, synchronically and diachronically, and together they have caused much confusion and influenced (often negatively) the development of the areas that they ostensibly name. (42)
\end{abstract}

We were pleased to see how well Hunt's essay on Children's Literature connected with Joseph Thomas's discussion - in his essay on Aesthetics - on the distinctions between "phenomenal beauty" as high-art and "mass-market popular" as low art. Overall, Hunt's essay on Children's Literature and Thomas's essay on Aesthetics provide an example of the enhanced features we wanted to build into our Keywords contour-mapping of the field. 
As our list of words and authors grew, we sometimes found that authors we had identified to write particular essays had other ideas for wordswhich turned out to be better than the suggestions we had given to them. We originally thought, for instance, that Philip Pullman, as author of the magnificent His Dark Materials trilogy (1995, 1997 and 2000) and the controversial The Good Man fesus and the Scoundrel Christ (2010) would be a great choice to write about Religion, a word we had chosen because it is entwined with so much children's book history and the history of reading instruction. Pullman suggested Intention instead, a word that we, as critics schooled in post-structuralist theories, had not anticipated. We assumed that "intention" was a dated critical word, one that had already been long out of the conflicted or contested categories. We were wrong. Pullman encouraged us to face head-on the uncomfortable truth that as readers we want to know, even when we do not necessarily acknowledge it, "how closely the interpretation matches the one the author intended" (128). He reminds us that people really do want to be assured that they "will not be shown up as ignorant of a truth that everyone knows." They want "an answer," the right answer. But as Pullman shows us in his essay, there is not always a right answer, and just because an author intends to write a certain kind of story, it does not mean that the story will turn out as the author intends.

Towards the end of his essay, Pullman reminds us that when readers are "puzzled" by a book, the best thing that they can do is talk about it, and "let meanings emerge from the conversation, democratically" (133). We took his advice to heart on more than one occasion and were pleased by the results. Marah Gubar was another author who ended up choosing her own word.

We had originally asked Gubar to write the Golden Age essay, as at the time she was just finishing the manuscript for Artful Dodgers: Reconceiving the Golden Age of Children's Literature. Instead, Gubar said that she would prefer to write about Innocence. It was an inspired choice. She begins her essay by noting the term's associations with both childhood and desire. Then she juxtaposes Shirley Temple's first films - shorts known as Baby Burlesks (which placed tiny children in compromising positions) against Playboy's "Playmate of the Month," which has, as Gubar notes, "a distinctly juvenile appellation." Innocence, she reminds us, was not always linked to childhood: prior to and during the nineteenth century, sin was linked to childhood. It was not until Locke, Rousseau and Wordsworth popularised notions of the innocent child - ideas that inspired much that is beneficial, including the late nineteenth-century social reform movements that banned child labour and led to free public education - that the sinful child was relegated to the past. What is particularly interesting about Gubar's essay is that she eloquently articulates the way a word as seemingly transparent as innocence has a complex history and an array of different uses and associations.

\section{READING KEYWORDS}

As we edited the Keywords essay drafts, we increasingly realised that the essays worked most effectively if there were references to ways in which particular terms could be applied to specific children's books and to specific critical approaches. So, we were pleased when we found that an individual work of children's literature turned up repeatedly in several categories, as when Carroll's Alice in Wonderland was cited in the Childhood, Classic, Golden Age and Liminality essays. From the very beginning of our Keywords work, we had hoped that an instructor putting together a syllabus for a course would be able to put a children's book on the course list and then access individual Keywords essays to demonstrate potential critical approaches to that book: that is, we hoped it would be possible to map a book by plotting keyword co-ordinates. That is, in fact, what happened.

Sherman Alexie's 2007 novel, The Absolutely True Diary of a Part-Time Indian turns up in essays on Boyhood, Class Identity, Postcolonial and Young Adult. Citing books about boyhood that depart from classic "boy's books," Eric Tribunella, author of the Boyhood essay, notes that Alexie's depiction of a Spokane Indian boy living on a Washington State reservation offers a more complex depiction of masculinity. Though Arnold Spirit (a.k.a. Junior) does play sports, athletics are not a major component of his story-he is poor, nerdy, an outcast both in his all-white school (as its sole Native American), and in his Spokane community (for choosing to go to the all-white school over the one on the reservation-or, "rez" as it is known colloquially). By focusing on Junior's class position, Liz Bullen, in the Class essay, cites the novel as an example of "issues of class" being "overwritten by race of ethnicity" (50). Clare Bradford, in her Postcolonial essay, sees the novel commenting on the influence of colonialism upon the lives of indigenous people (180). 
Considered in terms of her Identity essay, Karen Coats focuses on the challenges Junior faces in negotiating between his Native heritage and the white culture of his school. Ultimately, the friend who considered Junior a traitor for attending the white school suggests, as Coats says, that "Junior can still own his identity as an Indian because there is a stronger tradition of Indians as nomads than there is of Indians staying in one place as they do now on the rez" (112). Lee Talley, in Young Adult, locates Alexie's novel alongside other crossover books, such as Mark Haddon's The Curious Incident of the Dog in the Night-Time and Nancy Farmer's The House of the Scorpion. The shifting location of Alexie's story in the context of a range of Keywords essays, reinforces not only the idea that context creates meaning but also that meanings - like contexts - are multiple, overlapping and contingent.

We had a similar experience as we traced Frances Hodgson Burnett's 1911 classic, The Secret Garden, through the Keywords essays. In Kelly Hager's essay on Body, we were struck by her focus on "resurrection through touch, through taste, through smell, through the exercise of bodiliness" in The Secret Garden (19). Peter Hunt, in Children's Literature, identifies the novel as a children's book that had "crossed over" to classic status, partly "supported by academic, textual apparatus" (44). Mavis Reimer, in Home, attends to both literal and figurative sites in the novel in which "young people ... mother and nurture themselves" (196). Karen Coats, in Identity, explains how Mary "adjusts her behavior ... as part of her becoming a likeable young woman" (111). Peter Hollindale, in Nature, discusses "the mythical bonding between child and nature," and, finally, Kate Capshaw Smith, in Race reminds us about "the prejudicial constructions of race" in even the best-loved novels. As we flipped through the series of readings of The Secret Garden in the Keywords essays - from ideas of bodiliness, to identify, to crossover, to a warning example about prejudice, we felt as if we had been given instant access to a complete quick reference chart of interpretive possibilities.

\section{THE FUTURE OF KEYWORDS}

After Keywords for Children's Literature was published in 2011, we began taking it out for testdrives in our own courses. And we began obsessing about the words that got away: missing words, commissioned words that never made it into the published volume, and words we considered but then excluded because we thought they were clearly defined-so not meeting our "contested or conflicted" test. One phrase we would include now, but did not initially, was Children's Poetry. A conversation with Joseph Thomas (author of the Aesthetics essay) first made us think we did made a mistake by excluding Children's Poetry. Thomas pointed out that the Lion and the Unicorn Award for Excellence in North American Poetry (which appears annually in the September issue of the journal) is for a book of poetry - that is, for a book as a material object. In considering the genre of children's poetry, the book matters, as does its layout and often its accompanying images. We also remembered Richard Flynn's comments in his 'Fear of Poetry' essay for the Cambridge Companion to Children's Literature, in which he described the "vast bulk of children's poetry published today [as] goofy, sentimental or recycled from days of yore" (Flynn, 76). Both Flynn's comments and Thomas's alerted us to the fact that "children's poetry" is a conflicted term which engages the same constellation of concerns addressed in other essays in our volume, including Aesthetics, Popular, Classic and Golden Age - to name a few. We regret that we excluded Children's Poetry and would argue now for its inclusion in the second edition of Keywords for Children's Literature. Another term about which we are having second thoughts is Fairy Tale. We had excluded it originally on the grounds that it was a genre term, but given the recent debate about the origins of the fairy tale (literary works annexed by oral tradition vs. oral works fixed into literary tradition), we have reconsidered.

We have also become conscious of completely new directions we might consider for a future edition. Technology is high on our list, in terms of what and how we read and in theories of interpretation. As yet, there is little scholarship on enhanced eBooks for children, but if these do catch on - which appears likely - we will want to think about how that interactive medium works. In an enhanced eBook, the book can, in fact, read itself to you, highlighting each word as it is pronounced. And, as in the enhanced eBook of Peter Rabbit, it can have music and sound effects. Click on the animals and they make the appropriate noises: mice squeak, owls hoot and cats meow. Touch Peter Rabbit's mother and she hums, in a human voice. Touch Peter's sisters, and they giggle. Touch Peter, and he does too.

Reading may not, in fact be the correct word to describe the experience of an enhanced eBook. 
We do not read a film. We watch a film. We do not read a video game, we play a video game. Although reading can certainly occur in an enhanced eBook, perhaps we need a new verb. Work? Use? Play? Experience? What we do not necessarily do any more is turn paper pages.

Technologies of the future might also enable a Keywords project to be less Anglocentric. Although Google Translate may only offer fairly clunky translations at the moment, it is clear that software and technologies are improving. If so, then people who do not speak Norwegian or Swedish or Danish - the two of us for example - might have greater access to both literary and scholarly works in languages we do not speak. Of course, a more promising solution would be better and more authorised translations of children's books and scholarship, as would Anglophone scholars learning other languages and opening up to foreign scholarship and literature. We recognise that this solution would require structural changes in educational systems, but it is a goal worth pursuing.

Criticism, as well as literature, is also being changed by technology. By using emerging methodologies, such as "algorithmic" criticismdescribed by Stephen Ramsay in Reading Machines: Towards an Algorithmic Criticism - it is possible to begin to map, graphically, critical trends. In fact, graphic maps already turn up as images generated via texts fed into programmes, such as Google Ngram and Wordle (which makes "word clouds"). Michael Joseph, author of the Keywords essay on Liminality, suggests that it might be possible to put the digitised contents of all the articles from all the major children's literature journals into a "Wordsmith" programme, then, using the word frequency function, trace accurately the rise and fall of particular critical terms. We know that critical fashions change, so we could, theoretically, analyse the influence of various critical movements-Marxism, psychoanalysis, feminism, semiotics - on children's literature by tracking these terms through the journals. It would then be possible to map the changes. Although we cannot imagine a keyword that might come out of such a project at the moment, we can see that it might be able to spot emerging keywords, which would be of interest. On these glimpses of the possible future of both children's literature and children's literature criticism, we conclude by inviting you to join us in considering a future Keywords for Children's Literature. What keywords will need to be added to the map? Which texts (and words) would make a new edition less strictly Anglophone and more global? Should we get the opportunity to edit a revised version, we think that a richer, more inclusive map will improve the critical conversation, allowing readers to better navigate the dynamic landscape of children's literature.

\section{WORDS INCLUDED IN KEYWORDS FOR CHILDREN'S LITERATURE}

Aesthetics, African American, audience, body, boyhood, censorship, character, childhood, children's literature, class, classic, crossover literature, culture, domestic, education, empire, fantasy, gender, girlhood, golden age, graphic novel, home, identity, ideology, image, innocence, intention, Latino/a, liminality, literacy, marketing, modernism, multicultural, nature, nonsense, picture book, popular, postcolonial, postmodernism, queer, race, reading, realism, science fiction, story, theory, tomboy, voice, young adult.

\section{Note}

1. Unless otherwise noted, page numbers in parenthetical references are for our Keywords for Children's Literature.

\section{LITERATURE}

Alexie, Sherman. The Absolutely True Diary of a Part-Time Indian. New York: Little Brown, 2007.

Burnett, Frances Hodgson. The Secret Garden. Harmondsworth: Penguin-Puffin Books, 1911, 1951.

Burgett, Bruce, and Glenn Hendler. Keywords for American Cultural Studies. New York: New York University Press, 2007.

Darton, Frederick J. Children's Books in England: Five Centuries of Social Life. 1932. 3rd ed. revised by Brian Alderson. New York: Cambridge University Press, 1982.

Farmer, Nancy. The House of the Scorpion. 2002. New York: Atheneum, 2004.

Flynn, Richard. 'The Fear of Poetry.' In Cambridge Companion to Children's Literature, eds. Matthew O. Grenby and Andrea Immel, 76-90. Cambridge: Cambridge University Press, 2009.

Grenby, Matthew O. and Andrea Immel. Cambridge Companion to Children's Literature. New York: Cambridge University Press, 2009.

Gubar, Marah. Artful Dodgers: Reconceiving the Golden Age of Children's Literature. New York: Oxford University Press, 2009.

Haddon, Mark. The Curious Incident of the Dog in the NightTime. 2003. London: Definitions/Random House, 2004. 
Haugen, Tormod. Zeppelin. Trans. David R. Jacobs. Stroud, Gloucestershire: Turton and Chambers, 1991.

Hunt, Peter, ed., Children's Literature: The Development of Criticism. London: Routledge, 1990.

Hunt, Peter, ed., International Companion Encyclopedia of Children's Literature. 1996. 2nd ed. London: Routledge, 2004.

Hunt, Peter, ed. "RE: keywords (children's literature)." Email to Lissa Paul. 2 Dec. 2007.

Mickenberg, Julia and Lynne Vallone, eds., Oxford Handbook of Children's Literature. New York: Oxford University Press, 2011.

Nel, Philip and Lissa Paul, eds., Keywords for Children's Literature. New York: New York University Press, 2011.

Nodelman, Perry, ed., Touchstones: Reflections on the Best in Children's Literature. 3 vols. Lafayette: Children's Literature Association, 1985, 1987, 1989.

Potter, Beatrix. PopOut! The Tale of Peter Rabbit. LoudCrow Interactive, 2011. eBook.

Pullman, Philip. The Amber Spyglass. London: Scholastic, 2000.

Pullman, Philip. The Good Man Fesus and the Scoundrel Christ. Edinburgh: Canongate Books, 2010.

Pullman, Philip. Northern Lights. 1995. London: Scholastic, 1998.
Pullman, Philip. The Subtle Knife. 1997. London: Scholastic, 1998.

Ramsay, Stephen. Reading Machines: Towards an Algorithmic Criticism. Chicago: University of Illinois Press, 2011.

Trimmer, Sarah. The Guardian of Education, a Periodical work; consisting of a practical essay on Christian education founded immediately on the Scriptures and the Sacred Offices of the Church of England: Memoirs of Modern Philosophers, and Extracts from their Writings; Extracts from Sermons and Other books relating to Religious Education; and a copious Examination of Modern Systems of Education, Children's Books, and Books for Young Persons/Conducted by Mrs. Trimmer. Vol 1. London: J. Hatchard, 1802.

Williams, Raymond. Keywords: A Vocabulary of Culture and Society. 1976. rev. ed. New York: Oxford University Press, 1983.

Zipes, Jack, Lissa Paul, Lynne Vallone, Peter Hunt, and Gillian Avery, eds., The Norton Anthology of Children's Literature. New York: Norton, 2005. 